\title{
ADMISSION NEUTROPHIL TO LYMPHOCYTE AND PLATELET TO LYMPHOCYTE RATIO AS A PREDICTOR OF MORTALITY IN PATIENTS WITH SUBARACHNOID HEMORRHAGE
}

\author{
Ali YILMAZ*, Ayça ÖZKUL** \\ *Adnan Menderes University Faculty of Medicine, Department of Neurosurgery, Aydın, TURKEY \\ ** Adnan Menderes University Faculty of Medicine, Department of Neurology, Aydın, TURKEY
}

\begin{abstract}
INTRODUCTION: Inflammation is associated with the pathogenesis of subarachnoid hemorrhage (SAH) which is a serious disease with high mortality. NLR and PLR as novel inflammatory markers may serve as predictors of clinical severity and mortality in patients with SAH.

METHODS: Medical records of adult SAH patients who were admitted to our Neurology and Neurosurgery Departments were investigated. Clinical, neuroradiological, laboratory, and follow-up data were collected from electronic database. Admission complete blood count values including hemoglobin, leukocyte, neutrophil, platelet and mean platelet volume, neutrophil to lymphocyte ratio (NLR) and platelet to lymphocyte ratio (PLR) were also studied. Fisher score and mortality rates were also evaluated.

RESULTS: A total of 152 patients with a mean age of 52.94 $\pm 17.04(20-104)$ years, (94 (\%61.8) females and 58 (38.2\%) males) with SAH were included in the study. The patients were divided into two groups: aneurysmal (group 1, n:99) and nonaneurysmal SAH (group 2, n:53). In comparison of complete blood count parameters we found lower lymphocyte and higher neutrophil, NLR and PLR values in aneurysmal SAH patients who had also higher Fisher scores and mortality rate. There were also correlations between Fisher score and leukocyte, neutrophil, lymphocyte, NLR and PLR values. We also found that advanced age and higher NLR, PLR values are significantly related to mortality rates independent of presence of aneurysm.

DISCUSSION and CONCLUSION: Aneurysmal SAH patients had lower lymphocyte and higher neutrophil, NLR, PLR values with higher mortality rates and disease severity. Additionally advanced age and higher NLR, PLR values were significantly related to mortality rates independent of presence of aneurysm. We believe that NLR and PLR can be used as simple parameters to evaluate severity of SAH and short term mortality in clinical practice.
\end{abstract}

Keywords: Subarachnoid hemorrhage, neutrophil lymphocyte ratio, platelet lymphocyte ratio, mortality, Fisher score.

\section{SUBARAKNOID HEMORAJILİ HASTALARDA MORTALITTEYI ÖNGÖRMEDE NÖTROFIL / LENFOSITT VE} LENFOSIT / PLATELET ORANININ DURUMU

\section{ÖZET}

GİİS ve AMAÇ: İnflamasyon, mortalitesi yüksek ciddi bir hastalık olan subaraknoid hemorajiye (SAH) yol açan patogenez ile ilişkilidir. Yeni inflamatuvar belirteçler olarak NLR ve PLR, SAH'li hastalarda klinik şiddeti ve mortaliteyi öngörmede yardımcı olabilir.

YÖNTEM ve GEREÇLER: Nöroloji ve Nöroşirürji Kliniğimize başvuran erişkin SAH hastalarının tıbbi kayıtları araştırıldı. Elektronik veri tabanından klinik, nöroradyolojik, laboratuvar ve takip verileri toplandı. Hemoglobin, lökosit, nötrofil, trombosit ve ortalama trombosit hacmi, nötrofil ile lenfosit oranı (NLR) ve trombosit ile lenfosit oranını (PLR) içeren giriş kan sayım değerleri de çalışıldı. Fisher skoru ve mortalite oranları da değerlendirildi.

BULGULAR: Çalışmaya yaş ortalaması $52.94 \pm 17.04$ (20-104) yıl olan 94 (\% 61.8) kadın ve 58 (\% 38.2) erkek SAH'lı 152 hasta dahil edildi. Hastalar anevrizma (grup 1, n: 99) ve anevrizmal olmayan SAH (grup 2, n: 53) olmak üzere iki gruba

\footnotetext{
Corresponding author: Ali Yılmaz Assoc. Prof. MD. Adnan Menderes University, Faculty of Medicine, Department of Neurosurgery, Aydın, Turkey. Telephone: +904441256 E-mail: dryilmazali@gmail.com

Received: 15.01.2018 Accepted: 14.02.2018

This article should be cited as following: Yllmaz A, Özkul A. Admission neutrophil to lymphocyte and platelet to lymphocyte ratio as a predictor of mortality in patients with subarachnoid hemorrhage. Turkish Journal of Cerebrovascular Diseases 2018; 24 (1): 19-25. doi:10.5505/tbdhd.2018.57338
} 
ayrıldı. Tam kan sayımı parametrelerinin karşılaştırılmasında, daha yüksek Fisher skoru ve mortalite oranına sahip olan anevrizmal SAH hastalarında düşük lenfosit ve daha yüksek nötrofil, NLR ve PLR değerleri bulduk. Fisher skoru ile lökosit, nötrofil, lenfosit, NLR ve PLR değerleri arasında da korelasyon vardı. Ayrıca ilerlemiş yaş ve daha yüksek NLR, PLR değerlerinin anevrizma varlığından bağımsız olarak mortalite oranları ile önemli derecede ilişkili olduğunu bulduk.

TARTIŞMA ve SONUÇ: Anevrizmal SAH hastalarında daha yüksek mortalite oranları ve hastalık şiddeti ile, daha düşük lenfosit ve daha yüksek nötrofil, NLR, PLR değerleri vardı. Ayrıca ilerlemiş yaş ve daha yüksek NLR, PLR değerleri, anevrizma varlığından bağımsız olarak mortalite oranlarıyla anlamlı olarak ilişkiliydi. Klinik uygulamada SAH şiddetini ve kısa dönem mortaliteyi değerlendirmek için NLR ve PLR'nin basit parametreler olarak kullanılabileceğine inanıyoruz.

Anahtar Sözcükler: Subaraknoid hemoraji, nötrofil lenfosit oranı, platelet lenfosit oranı, mortalite, Fisher skoru.

\section{INTRODUCTION}

Subarachnoid hemorrhage (SAH) with or without an intracranial aneurysm is a serious health problem with a high mortality and morbidity. Although there are novel strategies and advances in management, it still carries high mortality (30-50\%) (1). The underlying mechanisms contributing to mortality following SAH hasn't been well defined yet. Early brain injury and late cerebral vasospasm are main pathophysiological mechanisms in where neuroinflammation and thrombotic reaction get involved $(2,3)$.

Novel studies suggested neuroinflammation as a key mediator of injury expansion (4-6). Peripheral immune cells are both recruited and activated in damaged tissue (7) and they can enter the brain parenchyma releasing inflammatory cytokines (8). Free radical mediated injury, microvascular changes, endothelial damage, neurotoxicity of blood breakdown products, coagulation disturbance and inflammatory processes are all likely to contribute to the worse clinical status of SAH (9).

Recently neutrophil to lymphocyte ratio (NLR) and platelet to lymphocyte ratio (PLR) has been confirmed as easily available biomarkers in systematic inflammation. NLR was found to be associated with outcome of intracerebral hemorrhage, SAH $(10,11)$ and cerebral ischemia (12) and PLR with myocardial infarction (13) and peripheral ischemia (14). It is well-known that systematic inflammation and hypercoagulation contribute to the worse clinical outcome of SAH. Therefore NLR and PLR may serve as predictors of clinical severity and mortality in patients with SAH. We also included the aneurysmal and nonaneurysmal SAH patients in our study to compare the possible differences of pathophysiologies in both groups.
Comparison of the NLR, PLR and other blood cound parameters of SAH patients with and without cerebral aneurysm has not been studied previously. Therefore, the first aim of this study was to compare these parameters in SAH patients. The second aim was to predict the correlation of NLR and PLR with Fisher score showing SAH severity. The third aim was to demonstrate the effect of these parameters on early mortality in $\mathrm{SAH}$ patients during hospitalization.

\section{MATERIAL AND METHODS}

In this study 152 patients with SAH who were admitted to our Neurology and Neurosurgery Departments between February 2015 and December 2016. The patients were diagnosed as having $\mathrm{SAH}$ according to noninvasive neuroimaging studies including computed tomography (CT), magnetic resonance imaging (MRI), CT angiography and MR angiography. The patients were divided into two groups: aneurysmal (group 1) and nonaneurysmal SAH (group 2). All subjects were within $24 \mathrm{~h}$ of initial symptom onset and had neurological examinations by a neurosurgeon or a neurologist. The patients were also analyzed according to Fisher scores. The cerebral DSA procedures were performed in the angiography suite to investigate cerebral aneurysm by an endovascular specialist within 248 hours (mean $6.5 \pm 0.96 \mathrm{~h}$ ). All aneurysmal SAH patients received endovascular or surgical treatments within 72 hours. Demographic data, comorbid diseases and previously used antiaggregant and anticoagulant medication were all investigated. Patients with hematologic, rheumatologic, endocrinologic disorders, malignancy, history of autoimmune disease and acute or chronic infection were all excluded. None of the participants had been taking immunsupressive drugs, antiaggregant, 
anticoagulants or analgesics. The blood samples were taken for laboratory tests including NLR, PLR and MPV within 24 hours after SAH. Both study groups were compared for complete blood count values including hemoglobin, leukocyte, neutrophil, platelet and mean platelet volume (mpv). Neutrophil to lymphocyte ratio (NLR) and platelet to lymphocyte ratio (PLR) were also studied as biomarkers of systematic inflammation. Fisher score and mortality rate during hospitalization were also assessed. The study was approved by the local ethics committee of our university.

\section{Statistical Analyses}

All statistical analyses were performed with SPSS 16.0 for Windows (SPSS Inc., Chicago, IL). Group comparisons were performed with Student's t-test for normally distributed continuous variables or Mann-Whitney U test for other continuous variables. Multiple mean comparisons were analyzed by one-way ANOVA, and $\mathrm{p}<0.05$ was considered statistically significant.

\section{RESULTS}

A total of 152 patients (94 (\%61.8) females and $58(38.2 \%)$ males) with SAH and with a mean age of $52.94 \pm 17.04$ (20-104) years were included in the study. The patients were divided into two groups: aneurysmal (group 1, n:99) and nonaneurysmal SAH (group 2, n:53). The demographic characteristics and Fisher score of both groups are shown in Table I. In comparison of complete blood count parameters we found higher neutrophil (10.52 (3.15-32.8) vs 7.13 (2.08-25.44) $\left.10^{3} / \mathrm{ul}, \mathrm{p}=0.016\right)$, NLR (8.48 (0.1-54.8) vs 3.56 (0.46-32.9) 0.002) and PLR values (184.06(2.3916.6) vs $133.7 \quad(33.48-579.5), p=0.026)$ in aneurysmal SAH patients. Although leukocyte values were also higher in this group (12.03 (2.5-
35) vs 10.3(5.07-33.5) $\left.10^{3} / \mathrm{ul}, \mathrm{p}>0.05\right)$ this didn't have statistical significancy. When we compared the severity of SAH, we found that patients with aneurysmal SAH had higher Fisher scores (4(1-4) vs 3 (1-4), $\mathrm{p}=0.008)$. As expected mortality rate was also higher in this group (27 $(27.3 \%)$ vs 8 (15.1\%), $\mathrm{p}=0.00$ ) (Table I). There were also correlations between Fisher score and leukocyte $(\mathrm{r}=0.380, \mathrm{p}=0.00)$, neutrophil $(\mathrm{r}=0.421, \mathrm{p}=0.00)$, lymphocyte $(\mathrm{r}=-0.273, \mathrm{p}=0.001)$, NLR ( $\mathrm{r}=0.394$, $\mathrm{p}=0.00)$, PLR ( $\mathrm{r}=0.236$, $\mathrm{p}=0.003)$.

We also evaluated patients with and without mortality in each group and compared all studied parameters in these subgroups.

In mortal aneurysmal SAH patients leukocyte (14.86 (6.3-35) vs $11.42(1.59-25.33) 10^{3} / \mathrm{ul}$, $\mathrm{p}=0.02)$, and neutrophil levels (13.06 (3.84-32.8) vs $\left.9.7(3.15-24.15) 10^{3} / \mathrm{ul}, \mathrm{p}=0.006\right)$ were elevated while lymphocyte count was found lower $(0.99$ (0.3-4.9) vs $\left.1.36(0.36-12.1) 10^{3} / \mathrm{ul}, \mathrm{p}=0.02\right)$ in this subgroup. NLR (13.26 (2.28-54.8) vs 7.55 (0.751.1), $\mathrm{p}=0.001)$ and PLR (235.5 (71.2-662.1) vs 163.71 (21.8-916.7), p=0.007) were also found higher than aneurysmal SAH patients without mortality (Table II). The similar results were also found in non-aneurysmal patients with mortality including higher NLR (9.75 (2.4-32.6) vs 3.05 (0.46-32.9), $\mathrm{p}=0.03)$, PLR (227.32 (134.2-481.1) vs $123.04 \quad(33.5-579.5), \quad p=0.00)$ and lower lymphocyte levels (1.11 (0.37-2.31) vs 1.88 (0.3911.7) $\left.10^{3} / \mathrm{ul}, \mathrm{p}=0.02\right)$. However leukocyte and neutrophil showed no statistically significancy (Table II). We also found that in both groups patients with mortality were older $(62.3 \pm 17.7$ vs $51.86 \pm 12.8, \mathrm{p}=0.006 ; 75.5 \pm 5.58$ vs $44.86 \pm 17.96$, $\mathrm{p}=0.00$ ) (Table II). Our data suggested that in SAH patients advanced age and higher NLR, PLR values are significantly related to mortality rates independent of presence of aneurysm (Figure I and II).

Table I. The demographic and clinical data of the patients with subarachnoid hemorrhage.

\begin{tabular}{|c|c|c|c|c|}
\hline & & SAH with aneurysm (n:99) & SAH without aneurysm (n:53) & $\mathrm{p}$ \\
\hline$\overline{\text { Age }}$ & & $54.79 \pm 15.01$ & $49.49 \pm 19.19$ & NS \\
\hline Gender male (\%) & & $40(40.4)$ & $18(34)$ & NS \\
\hline \multirow[t]{8}{*}{ Blood count } & Hemoglobin & $12.67 \pm 2.08$ & $12.20 \pm 2.24$ & NS \\
\hline & Leukocyte $\left(10^{3} / \mathrm{ul}\right)$ & $12.03(2.5-35)$ & $10.3(5.07-33.5)$ & NS \\
\hline & Neutrophil $\left(10^{3} / \mathrm{ul}\right)$ & $10.52(3.15-32.8)$ & $7.13(2.08-25.44)$ & 0.016 \\
\hline & Lymphocyte $\left(10^{3} / \mathrm{ul}\right)$ & $1.29(0.3-12.1)$ & $1.79(0.37-11.7)$ & 0.004 \\
\hline & Platelet $\left(10^{3} / \mathrm{ul}\right)$ & $252(50-466)$ & $262(98-710)$ & NS \\
\hline & MPV & $10.7(8.5-13.3)$ & $10.5(8.5-13.7)$ & NS \\
\hline & NLR & $8.48(0.1-54.8)$ & $3.56(0.46-32.9)$ & 0.002 \\
\hline & PLR & $184.06(2.3-916.6)$ & $133.7(33.48-579.5)$ & 0.026 \\
\hline Fisher & & $4(1-4)$ & $3(1-4)$ & 0.008 \\
\hline Mortality (\%) & & $27(27.3)$ & $8(15.1)$ & 0.00 \\
\hline
\end{tabular}


Yllmaz et al.

Table II. Comparison of aneurysmal and non-aneurysmal SAH patients with and without mortality.

\begin{tabular}{|c|c|c|c|c|c|c|c|}
\hline \multirow{3}{*}{\multicolumn{2}{|c|}{$\begin{array}{l}\text { Age } \\
\text { Gender male (\%) }\end{array}$}} & & & & & & \\
\hline & & $62.3 \pm 17.7$ & $51.86 \pm 12.8$ & 0.006 & $75.5 \pm 5.58$ & $44.86 \pm 17.96$ & 0.00 \\
\hline & & $10(37.03)$ & 14(41.67) & NS & $1(12.5)$ & $17(37.78)$ & NS \\
\hline \multirow[t]{9}{*}{ Blood count } & Hemoglobin & $12.29 \pm 2.01$ & $12.21 \pm 4.7$ & NS & $11.25 \pm 1.72$ & $12.4 \pm 2.3$ & NS \\
\hline & $\begin{array}{l}\text { Leukocyte } \\
\left(10^{3} / \mathrm{ul}\right)\end{array}$ & $\begin{array}{l}14.86 \\
(6.3-35)\end{array}$ & $\begin{array}{l}11.42 \\
(1.59-25.33)\end{array}$ & 0.02 & $\begin{array}{l}10.5 \\
(6.6-27.05)\end{array}$ & $\begin{array}{l}10.18 \\
(5.1-33.54)\end{array}$ & NS \\
\hline & $\begin{array}{l}\text { Neutrophil } \\
\left(10^{3} / \mathrm{ul}\right)\end{array}$ & $\begin{array}{l}13.06 \\
(3.84-32.8)\end{array}$ & $\begin{array}{l}9.7 \\
(3.15-24.15)\end{array}$ & 0.006 & $\begin{array}{l}8.96 \\
(3.7-25.44)\end{array}$ & $\begin{array}{l}6.65 \\
(2.08-24.1)\end{array}$ & NS \\
\hline & $\begin{array}{l}\text { Lymphocyte } \\
\left(10^{3} / \mathrm{ul}\right)\end{array}$ & $\begin{array}{l}0.99 \\
(0.3-4.9)\end{array}$ & $\begin{array}{l}1.36 \\
(0.36-12.1)\end{array}$ & 0.02 & $\begin{array}{l}1.11 \\
(0.37-2.31)\end{array}$ & $\begin{array}{l}1.88 \\
(0.39-11.7)\end{array}$ & 0.02 \\
\hline & $\begin{array}{l}\text { Platelet } \\
\left(10^{3} / \mathrm{ul}\right)\end{array}$ & $\begin{array}{l}260 \\
(90-415)\end{array}$ & $\begin{array}{l}247.5 \\
(58-456)\end{array}$ & NS & $\begin{array}{l}269.5 \\
(178-479)\end{array}$ & $\begin{array}{l}254 \\
(98-710)\end{array}$ & NS \\
\hline & MPV & $\begin{array}{l}10.7 \\
(8.6-13.3)\end{array}$ & $\begin{array}{l}10.65 \\
(8.5-12.8)\end{array}$ & NS & $\begin{array}{l}11.45 \\
(9.2-13.7)\end{array}$ & $\begin{array}{l}10.4 \\
(8.5-13.5)\end{array}$ & NS \\
\hline & NLR & $\begin{array}{l}13.26 \\
(2.28-54.8)\end{array}$ & $\begin{array}{l}7.55 \\
(0.7-51.1)\end{array}$ & 0.001 & $\begin{array}{l}9.75 \\
(2.4-32.6)\end{array}$ & $\begin{array}{l}3.05 \\
(0.46-32.9)\end{array}$ & 0.03 \\
\hline & PLR & $\begin{array}{l}235.5 \\
(71.2-662.1)\end{array}$ & $\begin{array}{l}163.71 \\
(21.8-916.7)\end{array}$ & 0.007 & $\begin{array}{l}227.32 \\
(134.2-481.1)\end{array}$ & $\begin{array}{l}123.04 \\
(33.5-579.5)\end{array}$ & 0.00 \\
\hline & & $4(1-4)$ & $4(1-4)$ & NS & $2.5(1-4)$ & $3(1-4)$ & NS \\
\hline
\end{tabular}

Data are given as median (minimum-maximum) values except hemoglobin which is given as mean \pm standart deviation since it is distributed normally. NS= not significant.
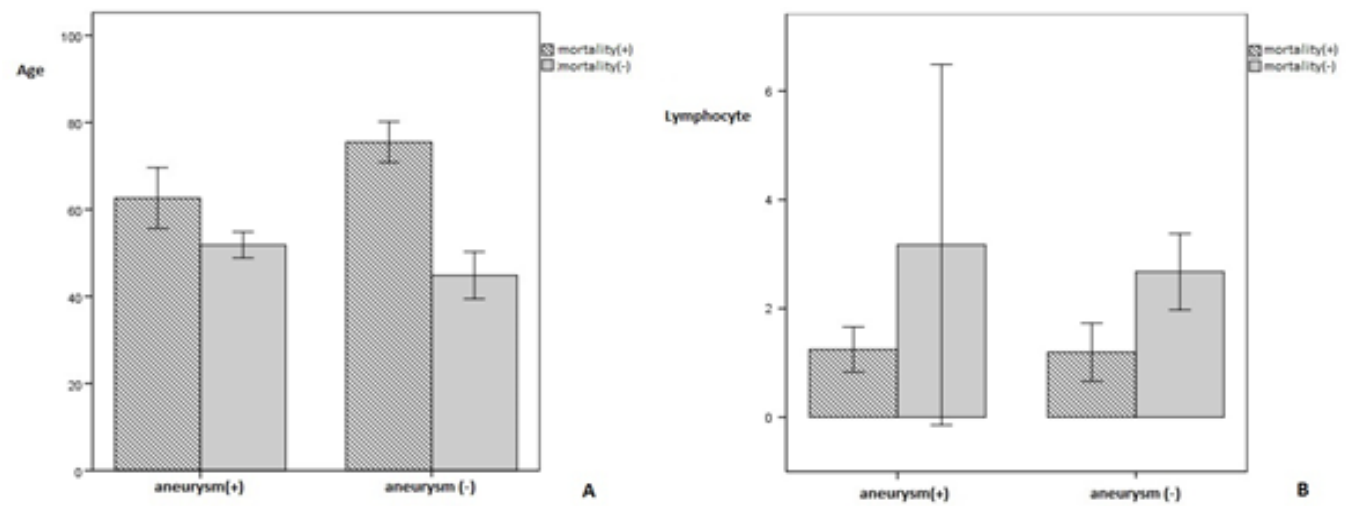

Figure I. Figure showing the differences of $(A)$ age $(62.3 \pm 17.7$ vs $51.86 \pm 12.8, p=0.006 ; 75.5 \pm 5.58$ vs $44.86 \pm 17.96, p=0.00)$ and $(B)$ lymphocyte count $\left(0.99(0.3-4.9)\right.$ vs $1.36(0.36-12.1) 10^{3} / \mathrm{ul}, \mathrm{p}=0.02 ; 1.11(0.37-2.31)$ vs $\left.1.88(0.39-11.7), 10^{3} / \mathrm{ul} \mathrm{p}=0.02\right)$ between aneurysmal SAH with and without mortality.
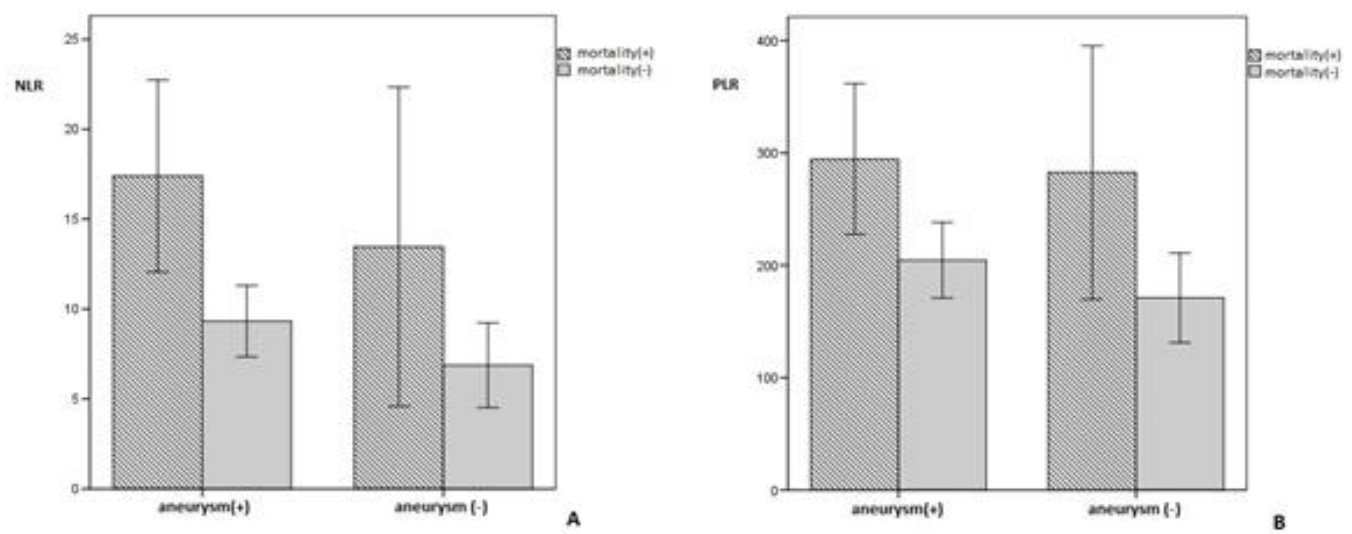

Figure II. Figure showing the differences of (A) NLR (13.26 (2.28-54.8) vs 7.55 (0.7-51.1), p=0.001; 9.75 (2.4-32.6) vs 3.05 (0.46-32.9), $\mathrm{p}=0.03)$ and (B) PLR values (235.5 (71.2-662.1) vs 163.71 (21.8-916.7), $\mathrm{p}=0.007 ; 227.32$ (134.2-481.1) vs 123.04 (33.5-579.5) p=0.00) between aneurysmal SAH with and without mortality. 


\section{DISCUSSION}

In this study we found higher neutrophil, NLR, PLR and lower lymphocyte values in aneurysmal SAH patients who also had higher mortality rates and Fisher scores suggesting severe SAH. To our knowledge there hasn't been a study comparing complete blood count values including hemoglobin, leukocyte, neutrophil, platelet, mpv, as well as NLR and PLR as biomarkers of systematic inflammation in SAH with and without cerebral aneurysm. Our data suggested that aneurysmal SAH had higher systemic inflammation than nonaneuyrsmal SAH patients. Although endothelial dysfunction which also contributes inflammation is well known in the pathogenesis of both aneurysmal and spontaneous SAH patients, there are only limited data on this subject $(15,16)$.

Mechanisms under NLR, PLR and SAH severity remain largely unknown. High neutrophil and NLR, PLR values reflect inflammation whereas low lymphocyte count is a sign of poor general health and physiological stress (17). Prognostic value of NLR and PLR are related to inflammatory response which is critically involved in the pathogenesis of SAH (18). Recent studies suggested that neuroinflammation plays a critical role in both early brain injury and the delayed brain deterioration after $\mathrm{SAH}$, including cellular and molecular components. As hemorrhage occurs, immunomodulatory cells within the central nerve system, such as microglia are activated. This causes upregulation of numerous cell adhesion molecules within endothelial cells. Subsequently inflammatory cells, macrophages and neutrophils phagocytize the extravasated, degrading red blood cells. This process occurs as a response to hemorrhage in order to clear free hemoglobin, and promote neurostability and recovery $(19,20)$. Neuroinflammation contributes to cerebral vasospasm causing delayed cerebral ischemia. Additionally systemic inflammatory response syndrome (SIRS) commonly occurs in the SAH patients, causing non-infectious fever and systematic complications (19). Therefore, assessment of inflammatory response in SAH has an important clinical value for the prognosis of disease.

In this study we also found positive correlations between Fisher score and leukocyte, neutrophil, NLR and PLR. Fisher scores also found to be higher in patients with lower lymphocyte values. All these data suggested that patients with severe hemorrhage had higher leukocyte, neutrophil, NLR and PLR but lower lymphocyte values. Accordingly, these parameters may be used as predictors of severe SAH. It is also known that other increased inflammatory markers such as Creactive protein, and erythrocyte sedimentation rate (ESR) (21) were associated with severe SAH with poor outcomes of SAH. A recent study also revealed that increased NLR and PLR are associated with poor outcomes at 3 months (10). However there are limited data about the exact mechanism of this relationship between NLR, PLR, neutrophil, lymphocyte and Fisher scores showing SAH severity.

NLR and PLR are novel composite inflammatory markers in the area of vascular pathologies including cerebral iscemia, intracerebral hemorrhage, venous thromboembolism $(10,11,17)$. It has been also shown that increased platelet activation plays an important role in the initiation and progression of atherosclerosis. It is well known that several inflammatory mediators including the proinflammator cytokines interleukin- 6 and tumor necrosis factor-alpha stimulate megakaryocytic proliferation and induce reactive thrombocytosis (22). Besides a direct role in haemostasis and thrombus formation, high platelet counts may reflect underlying inflammation. Therefore both NLR and PLR are parameters related to the inflammatory reaction. Recent studies have demonstrated that NLR and PLR is associated with adverse cardiovascular outcome $(13,23)$. They are combined indices reflecting both the proinflammatory/procoagulant status which may provide an additional information to both disease severity as well as mortality.

It has been previously shown that aneurysmal SAH patients had higher mortality rates and Fisher scores suggesting more severe SAH when compared with nonaneurysmal SAH $(24,25)$. Cerebral aneurysm which is associated with vascular or other factors may worsen the amount of bleeding. Therefore, aneurysmal cases have more blood, which may be associated with higher systemic inflammatory response and worse clinical status with higher Fisher scores.

We also investigated the effect of these parameters on early mortality in SAH patients during hospitalization. In nonaneurysmal $\mathrm{SAH}$ patients, there were no differences with regard to 
leukocyte and neutrophil count in subgroups with and without mortality. The only statistical differences were found in lymphocyte, NLR, PLR and age parameters between nonaneurysmal SAH with and without mortality. However in aneurysmal SAH lymphocyte values were lower and neutrophil, leukocyte, PLR, NLR values were found higher in the mortal subgroup.

Our data suggested that lower lymphocte, advanced age and higher NLR, PLR values are significantly related to mortality rates independent of presence of aneurysm. Advanced age is a well known factor for mortality in SAH (26). Although elevated leukocyte and NLR values, and lower lymphocyte count have been shown to be related with hospital mortality in SAH, there are no data about their relationship with cerebral aneurysm (27).

It has been previously shown that NLR predicts short-term mortality after cerebral ischemia independent of infarction size $(12,28)$. In a recent study NLR and PLR were found as independent predictors of delayed cerebral ischemia development and worse functional outcome after acute aneurysmal SAH (10). Taken together, all these results indicate that inflammation at least partially mediates the linkage between the short term mortality of SAH with lymphopenia, NLR and PLR.

Our study has several limitations. It was designed as a cross-sectional study, therefore we didn't follow-up the patients and explored the relation between long term outcomes and inflammatory parameters. Secondly, we did not evaluate the other inflammatory markers such as TNF-alpha, IL-1b, IL-6, ESR and highly sensitive CRP in our patients. It would be much better to compare our parameters with inflammatory markers to determine more definite results. Inflammation may also play a role in delayed cerebral ischemia which may cause poor outcome. Unfortunately we didin't evaluate cerebral vasospasm and delayed cerebral ischemia. It would be a study of interest to determine the relationship between inflammation and delayed cerebral ischemia in further studies with more detailed larger study groups.

In conclusion aneurysmal SAH patients had lower lymphocyte and higher neutrophil, NLR, PLR values with higher mortality rates and Fisher scores suggesting severe SAH. We also found that there are correlations between severity of hemorrhage and lymphocyte, leukocyte, neutrophil, NLR and PLR values. Comparison of the NLR, PLR and other blood count parameters of SAH patients with and without cerebral aneurysm hasn't been studied before in the literature. Our data suggested advanced age and higher NLR, PLR values are significantly related to mortality rates independent of presence of aneurysm. Therefore NLR and PLR seem to be simple parameters to evaluate severity of SAH and short term mortality, and this could be part of neurological evaluation before SAH treatment especially in advanced aged with decreased lymphocyte count.

\section{REFERENCES}

1. Broderick JP, Brott TG, Duldner JE, Tomsick T, Leach A. Initial and recurrent bleeding are the major causes of death following subarachnoid hemorrhage. Stroke. 1994;25:1342-1347

2. Lucke-Wold BP, Logsdon AF, Manoranjan B, et al. Aneurysmal subarachnoid hemorrhage and neuroinflammation: a comprehensive review. Int J Mol Sci. 2016;17:497. doi:10.3390/ijms 17040497.

3. Terpolilli NA, Brem C, Buhler D, Plesnila N. Are we barking up the wrong vessels? Cerebral microcirculation after subarachnoid hemorrhage. Stroke. 2015;46:3014-9.

4. Lucke-Wold BP, Logsdon AF, Manoranjan B, Turner RC, McConnell E, Vates GE, Huber JD, Rosen CL, Simard JM. Aneurysmal Subarachnoid Hemorrhage and Neuroinflammation: A Comprehensive Review. Int J Mol Sci. 2016 Apr 2;17(4):497.

5. Caffes, N.; Kurland, D.B.; Gerzanich, V.; Simard, J.M. Glibenclamide for the treatment of ischemic and hemorrhagic stroke. Int. J. Mol. Sci. 2015, 16, 4973-4984. [CrossRef] [PubMed]

6. Makino, H.; Tada, Y.; Wada, K.; Liang, E.I.; Chang, M.; Mobashery, S.; Kanematsu, Y.; Kurihara, C.; Palova, E.;Kanematsu, M.; et al. Pharmacological stabilization of intracranial aneurysms in mice: A feasibility study. Stroke 2012, 43, 2450-2456.

7. Moraes, L.; Grille, S.; Morelli, P.; Mila, R.; Trias, N.; Brugnini, A.; N, L.L.; Biestro, A.; Lens, D. Immune cells subpopulations in cerebrospinal fluid and peripheral blood of patients with aneurysmal subarachnoid hemorrhage. SpringerPlus 2015, 4, 195.

8. Sarrafzadeh A, Schlenk F, Gericke C, et al. Relevance of cerebral interleukin-6 after aneurysmal subarachnoid hemorrhage. Neurocrit Care 2010;13:339-46.

9. McMahon CJ, Hopkins S, Vail A, King AT, Smith D, Illingworth KJ, Clark S, Rothwell NJ, Tyrrell PJ. Inflammation as a predictor for delayed cerebral ischemia after aneurysmal subarachnoid haemorrhage. J Neurointerv Surg. 2013 Nov;5(6):512-7.

10. Tao C, Wang J, Hu X, Ma J, Li H, You C. Clinical Value of Neutrophil to Lymphocyte and Platelet to Lymphocyte Ratio After Aneurysmal Subarachnoid Hemorrhage. Neurocrit Care. 2016 Dec 27.

11. Lattanzi S, Cagnetti C, Provinciali L, Silvestrini M. Neutrophil to lymphocyte ratio predicts the outcome of acute intracerebral hemorrhage. Stroke. 2016;47:1654-7.

12. Celikbilek A, Ismailogullari S, Zararsiz G. Neutrophil to lymphocyte ratio predicts poor prognosis in ischemic cerebrovascular disease. J Clin Lab Anal. 2014;28:27-31. 
13. Kurtul A, Yarlioglues M, Murat SN, et al. Usefulness of the platelet-to-lymphocyte ratio in predicting angiographic reflow after primary percutaneous coronary intervention in patients with acute st-segment elevation myocardial infarction. Am J Cardiol. 2014;114:342-7.

14. Gary T, Pichler M, Belaj K, et al. Platelet-to-lymphocyte ratio: a novel marker for critical limb ischemia in peripheral arterial occlusive disease patients. PLoS ONE. 2013;8:e67688.

15. Matthew J. McGirt, John R. Lynch, Augusto Parra, Huaxin Sheng, Robert D. Pearlstein, Daniel T. Laskowitz, Dale A. Pelligrino and David S. Warner Simvastatin Increases Endothelial Nitric Oxide Synthase and Ameliorates Cerebral Vasospasm Resulting From Subarachnoid Hemorrhage. Stroke. 2002;33:2950-2956,

16. Hendrix P, Foreman PM, Harrigan MR, Fisher WS Rd, Vyas NA, Lipsky RH, Lin M,Walters BC, Tubbs RS, Shoja MM, Pittet JF, Mathru M, Griessenauer CJ. Endothelial nitric oxide synthase polymorphism is associated with delayed cerebral ischemia following aneurysmal subarachnoid hemorrhage. World Neurosurg. 2017 Feb 22. pii: S18788750(17)30235-8.

17. Ferroni P, Riondino S, Formica V, Cereda V, Tosetto L, La Farina F, Valente MG, Vergati M, Guadagni F, Roselli M. Venous thromboembolism risk prediction in ambulatory cancer patients: clinical significance of neutrophil/lymphocyte ratio and platelet/lymphocyte ratio. Int J Cancer. 2015 Mar 1;136(5):1234-40.

18. Provencio JJ and Vora N. Subarachnoid hemorrhage and inflammation: bench to bedside and back. Semin Neurol. 2005; $25:$ 435-44.

19. Zheng VZ, Wong GK Neuroinflammation responses after subarachnoid hemorrhage: A review.J Clin Neurosci. 2017 Mar 13. pii: S0967-5868(16)31207-3.

20. Sarrafzadeh A, Schlenk F, Meisel A, Dreier J, Vajkoczy P, Meisel C. Immunodepression after aneurysmal subarachnoid hemorrhage. Stroke. 2011 Jan;42(1):53-8.
21. Juvela S, Kuhmonen J and Siironen J. C-reactive protein as predictor for poor outcome after aneurysmal subarachnoid haemorrhage. Acta Neurochir (Wien). 2012; 154:397-404.

22. Heits F, Katschinski DM, Wilmsen U, et al. Serum thrombopoietin and interleukin 6 concentrations in tumour patients and response to chemotherapy-induced thrombocytopenia. Eur J Haematol 1997;59:53-8

23. Sari I, Sunbul M, Mammadov C, Durmus E, Bozbay M, Kivrak T, Gerin F. Relation of neutrophil-to-lymphocyte and platelet-to-lymphocyte ratio with coronary artery disease severity in patients undergoing coronary angiography. Kardiol Pol. 2015;73(12):1310-6. doi: 10.5603/KP.a2015.0098. Epub 2015 May 19.

24. Tsermoulas G,Flett L, Gregson B, Mitchell P. Immediate coma and poor outcome in subarachnoid haemorrhage are independently associated with an aneurysmal origin. Clinical Neurology and Neurosurgery 2013;115:13621365.

25. Konczalla J, Platz J, Schuss P, Vatter H, Seifert V, Guresir E. Non-aneurysmal non-traumatic subarachnoid hemorrhage: patient characteristics, clinical outcome and prognostic factors based on a single-center experience in 125 patients. BMC Neurology 2014; 14:140

26. Lantigua H, Ortega-Gutierrez S, Schmidt JM, Lee K, Badjatia $\mathrm{N}$, Agarwal S,Claassen J, Connolly ES, Mayer SA. Subarachnoid hemorrhage: who dies, and why?Crit Care. 2015 Aug 31;19:309.

27. Huang YL, Han ZJ, Hu ZD. Red blood cell distribution width and neutrophil to lymphocyte ratio are associated with outcomes of adult subarachnoid haemorrhage patients admitted to intensive care unit. Ann Clin Biochem. 2017 Jan 1:4563216686623 doi:10.1177/0004563216686623.

28. Tokgoz S, Keskin S, Kayrak M, Seyithanoglu A, Ogmegul A. Is neutrophil/lymphocyte ratio predict to short-term mortality in acute cerebral infarct independently from infarct volume? J Stroke Cerebrovasc Dis. 2014;23:21632168. 